University of Nebraska - Lincoln

DigitalCommons@University of Nebraska - Lincoln

1980

\title{
Quantitative Demonstration of Cell Surface Involvement in a Plant- Animal Symbiosis: Lectin Inhibition of Reassociation
}

\author{
R. H. Meints \\ University of Nebraska - Lincoln \\ Rosevelt L. Pardy \\ University of Nebraska - Lincoln, rpardy2@unl.edu
}

Follow this and additional works at: https://digitalcommons.unl.edu/bioscifacpub

Part of the Life Sciences Commons

Meints, R. H. and Pardy, Rosevelt L., "Quantitative Demonstration of Cell Surface Involvement in a PlantAnimal Symbiosis: Lectin Inhibition of Reassociation" (1980). Faculty Publications in the Biological Sciences. 75.

https://digitalcommons.unl.edu/bioscifacpub/75

This Article is brought to you for free and open access by the Papers in the Biological Sciences at DigitalCommons@University of Nebraska - Lincoln. It has been accepted for inclusion in Faculty Publications in the Biological Sciences by an authorized administrator of DigitalCommons@University of Nebraska - Lincoln. 


\title{
QUANTITATIVE DEMONSTRATION OF CELL
} SURFACE INVOLVEMENT IN A PLANT-ANIMAL SYMBIOSIS: LECTIN INHIBITION OF REASSOCIATION

\author{
R. H. MEINTS AND R. L. PARDY \\ School of Life Sciences, University of Nebraska, Lincoln, Nebraska, 68588, U.S.A.
}

\section{SUMMARY}

The freshwater hydra, Hydra viridis is normally associated with Chlorella-like, algal symbionts which inhabit the host's digestive cells. Under experimental conditions bleached hydra will reassociate with algae harvested from green hydra, but not from our cultures of wild type Chlorella or strain NC64A which when originally isolated from Paramecium bursaria was symbiotically competent. Because of its demonstrated selectivity, the reassociation process is hypothesized to involve a recognition interface whose active participants are the algae cell wall and the digestive cell membrane. The data presented here confirm the hypothesis and suggest some potential molecular characteristics of the interacting partners.

Concanavalin A (Con A), a plant lectin, used widely for similar studies in other systems totally inhibits reassociation; Wheat Germ Agglutinin (WGA), ricin and Lens culinaris lectin do so to a lesser degree. These results are consistent with the hypothesis that glycoproteins on the cells' peripheries are involved in cell-cell recognition in this system.

\section{INTRODUCTION}

It is well established that the freshwater hydra, Hydra viridis, can acquire and maintain eukaryotic algae as functional, hereditary endosymbionts. A key aspect of the symbiosis is the ability to reassociate the host and symbionts experimentally under controlled conditions and bring about a re-establishment of the symbiotic relationship. Muscatine, Cook, Pardy \& Pool (I975) present a thorough review of this aspect of the association.

The work of Pardy \& Muscatine (I973) showed that successful reproduction of the symbiosis is a multistep process involving a high degree of specificity between the host and putative symbionts. Moreover, they suggested that a recognition phenomenon involving the contact of symbiotic algae with the host cells was the basis of the observed specificity.

A growing body of literature in other systems has implicated a variety of biochemical species, which are bound integrally to surface membranes, and which appear to be crucial to cell-cell recognition phenomena. Surface related chemical sites which mediate cell-cell, molecule-molecule and molecule-cell interactions are highly specific and at least one of the interacting species has frequently shown to be a glycoprotein (Oseroff, Robbins \& Burger, 1973). These interacting or recognition molecules have been characterized in a variety of animal and plant cells and develop- 
mentally regulated systems, i.e. embryonic cells (Moscona, I974), the differentiating cellular slime mould Dictyostelium discoideum (Rosen, Kafka, Simpson \& Barondes, I973), tumour cells (Burger, 1969), antigens in development (Edidin, 1976), the immune reaction (Yahara \& Edelman, 1972; Edidin \& Weiss, 1972; Loor, Formi \& Pernis, 1972), hormone receptor sites (Cuatrecasas, 1973, 1974), and the location and distribution of amino acid and carbohydrate transport sites (Inbar, Ben-Bassat \& Sachs, I971).

A class of protein/glycoprotein molecules that shows a high degree of specificity in binding to sites on cell surfaces are the plant and animal lectins. Derived primarily from legume seeds, lectins display extensive abilities to interact with and bind to an array of macromolecules. The binding is a result of the lectin's specific affinities for carbohydrates, generally limited to a few residues, terminal glycosides or sub-portions thereof. Concanavalin A (Con A) prepared from the jackbean, Concanavalin ensiformis, is a lectin which binds to $\alpha$-D-glucopyranosyl, $\alpha$-D-mannopyranosyl, $\alpha-N$-acetyl-Dglycosamines (Goldstein \& So, 1965; So \& Goldstein, I967), $\beta$-D-fructofuranosyl and $\alpha$-D-arabinofuranosyl residues (Sharon $\& \mathrm{Lis}, \mathrm{I} 972$ ). Polysaccharides such as glycogen, amylopectin, mannans, D-fructans, levans and arabinogalactans can all be bound to and precipitated by Con A.

The experimental utility of plant lectins lies in their value as specific probes in the analysis of cell surfaces. Cell surfaces from a variety of different kinds of cells depending upon their component glycosides, show varying degrees of reactivity to one or a combination of lectins. Information with respect to this reactivity can be used to assess the role(s) of cell surfaces in various biological processes, for example cell-cell recognition and to provide a first-order description of some surface-binding moieties.

The study described here addresses the question of what mechanism(s) underlies the specific interactions between partners in a symbiotic relationship. In addition we describe a rapid and effective technique for analysing the experimental reassociation of a hydra-algae symbiosis. The data presented are consistent with the hypothesis that both partners bear specific surface recognition sites that can be totally inhibited with Con $A$ and to a lesser extent with other lectins and which play a key role in symbiont reassociation.

\section{MATERIALS AND METHODS}

\section{Experimental organisms}

Mass cultures of hydra (Hydra viridis, Florida strain) were reared and maintained in $\mathbf{M}$ solution according to the methods of Lenhoff \& Brown (1971). The animals were fed daily on a diet of freshly hatched nauplii from the brine shrimp, Artemia salina, and maintained in an incubator at $20^{\circ} \mathrm{C}$ with a $\mathrm{r} 2-\mathrm{h}$ photoperiod. Illumination was provided by a $40-\mathrm{W}$ fluorescent tube which emitted approximately $\mathrm{I}_{2} \mathrm{~W} \mathrm{~W}^{-1}$ (YSI Model $65 \mathrm{~A}$ Radiometer) as measured in the centre of the incubator. Aposymbiotic (= algae free) hydra were prepared by photobleaching (Pardy, 1976) and were cultured as described above for green hydra.

In some experiments symbionts from Paramecium bursaria (strain NC64A) were used. These symbiotic algae were cultured in either nutrient broth or nutrient agar prepared from Difco Chlorella broth. Slants and liquid culture of symbionts were maintained at room temperature under Gro-Lux lamps providing continuous illumination of $3.0 \mathrm{~W} \mathrm{~m}^{-2}$.

Symbiotic algae used in experiments were harvested from daily fed mass cultures of green 
hydra. In practice, I 50-300 hydra were homogenized in M solution using a tissue homogenizer. Symbiotic cells were separated from the animal homogenate by low speed centrifugation using an IEC clinical centrifuge.

\section{Algal preparation}

Algae and their interactions with hydra aposymbionts were studied in a variety of preparations. Algae isolated from freshly homogenized green hydra were treated twice (at $5 \mathrm{~min}$ ) with $0.5 \%$ sodium dodecyl sulphate (SDS) in $M$ solution followed by 3 washes in $M$. This treatment rendered the algal cells essentially free of hydra tissue remnants as revealed by microscopic observation and was used where indicated as the standard method of preparing symbionts.

\section{Symbiont quantification}

Historically, estimation of the quantitative relationship of symbiotic partners required extensive microscopical analysis of aposymbiont tissues. These procedures are laborious, time consuming and only analyse a small population of host digestive cells. We present here an improved approach to these estimations based on the fluorescent emission of chlorophyll, the functional molecule of algal photosynthesis. This molecule can be quickly and quantitatively extracted from isolated algae, green hydra and from reconstituted aposymbionts. The method is an elaboration of one originally suggested by $\mathrm{Dr} \mathrm{C}$. D'Elia (personal communication).

In practice any of the 3 forms were isolated, placed in $4 \mathrm{ml}$ of analytical grade methanol and extracted maximally, a period requiring minimally $30 \mathrm{~min}$. Analysis was made directly using a Turner Model no. II I fluorimeter equipped with a red-sensitive photomultiplier developed specifically for chlorophyll analysis, a band pass filter and an ultraviolet excitation source. With this system, chlorophyll quantification of single green hydra or of a reconstituted aposymbiont is possible. Furthermore, theoretically, chlorophyll concentration from as few as rooo isolated algae can be determined. The Turner fluorimeter exhibits a high degree of sensitivity requiring modification of the instrument in our experiments. Because of the intense fluorescence of some samples, the sensitivity of the instrument was reduced by the use of attenuation slits of $0.187 \mathrm{~mm}$ (slit I) and $3.7 \mathrm{~mm}$ (slit 2) placed between the sample and the photomultiplier tube. Moreover, the incident light was controlled in I, 3, ro and 30 times increments. This procedure allowed ready application of the technique to a variety of algal concentrations. Full sensitivity readings along with those from both slits showed linear correlations with chlorophyll concentration.

Estimates of chlorophyll concentration based on fluorimetric analysis were correlated to spectrophotometric measurements (MacKinney, I941).

\section{Experimental}

Symbiotic reassociation was studied under a variety of conditions. Aposymbionts were fed daily. 'Standard' experimental animals, i.e. those with a single immature bud, were injected with experimental algae $48 \mathrm{~h}$ after their last feeding. This time was chosen based on observations that maximal reassociation occurred under these feeding conditions. During the preinjection period and throughout the course of the experiment, animals were held under controlled temperature and photoperiod conditions as already described.

Algae, treated or untreated, were reduced to a dense slurry by centrifugation. This cell suspension was injected directly into the gastric cavity of aposymbiotic hydra using a micropipette as described by Pardy \& Muscatine (1973). A modification of their procedure involved use of breath-aspirated hand-drawn glass micropipettes rather than a syringe apparatus as originally described. Under most conditions injected aposymbionts were held for $24 \mathrm{~h}$ before analysis to allow reassociation to come to completion and to ensure that algae not taken up by digestive cells were cleared from the gastric cavity. In those experiments requiring analysis at times less than $24 \mathrm{~h}$, non-associated algae were removed from the gastric cavity by slitting the hydra and gently lavaging the host tissues free of contaminants.

Since hydra hosts are fed to repletion daily up to $48 \mathrm{~h}$ before injection they display minimumtime reproductive turnover. Injected aposymbionts continue to produce buds which are found in various stages of development throughout the experimental period. Mature buds at injection generally remain free of algae while immature buds do not, but frequently remain attached at 
analysis time. To avoid contribution of these elements to the data set, all buds were surgically excised immediately prior to analysis.

\section{Algae treatments}

The question of surface interactions is pivotal to this study. The first principle to be established was the implication of these elements in algal-hydra reassociation. The primary tools selected were specific lectins which would bind to theorized recognition molecules of cell wall and cell membrane components of the symbiotic partners. Since quantitative application of lectin to hydra cells is difficult to control, treatments were more routinely applied to the algal partners. Experiments are presented which indicate that lectins applied to the digestive cell membranes are also effective at low doses.

Con A was chosen as the primary probe since it has strong affinities for several molecules implicated in cell wall and plasma membrane components of this system. Additionally, ricin, wheat germ agglutinin and Lens culinaris lectin were also surveyed. Lectins prepared in M solution were incubated with algal cell preparations for $\mathrm{I} h$ at $20^{\circ} \mathrm{C}$. Prior to injection, cells were washed 3 times with $M$ solution. The concentrations of cells and lectins are included in figure and table legends. In those experiments involving the direct exposure of hydra digestive cells to lectins, the animals were immersed in lectin solution prepared in $M$ as well as injected with M-containing lectin. After incubation for $\mathrm{I} \mathrm{h}$ at $20^{\circ} \mathrm{C}$ the animals were removed from the lectin solution and the enteron was washed with several injections of $M$ (lectin free) followed by injection of freshly prepared algae.

\section{RESULTS}

The establishment of a simple, reproducible and quantitative technique for algaehydra reassociation was crucial to this study. Figs. I-4 present data from the fluorometric approach which was adopted. Fig. I presents data from the lowest sensitivity setting we were able to achieve (slit 2, IX incident light). Under this configuration the fluorimeter was maximally attenuated and numbers of algae ranging between 0.5 and $20 \times 10^{6}$ cells per $4 \mathrm{ml}$ extraction could be easily measured. In Fig. 2, lower numbers of algae, ranging between $10^{4}$ and $5 \times 10^{5}$ per extraction, are also shown to be linearly related when measured with slit $I$ and IX incident light. Fig. 3 relates the fluorimetric measurements (slit $2,1 \mathrm{X}$ ) as arbitrary units to the measured concentrations of chlorophyll as $\mu \mathrm{g}$ per algal cell extracted and thus Fig. 4 can be drawn relating the amount of chlorophyll to cells ranging in number up to $20 \times 10^{\circ}$ cells. Each of the slits employed in combination with several attenuations of incident light has been calibrated on uniform algae preparations and thus by calculation each reading at a given attentuation combination can be converted to all of the other combinations.

Using these techniques for subsequent studies the amounts of chlorophyll in individual or multiples of hydra were measured. Fig. 5 summarizes these findings. Curves $A$ and $B$ result from a regression analysis of 2 experiments which are the range of the studies. Each line is based on measurements of 1,2 , 3, etc., up to 8 hydra per extraction. Line $C$ is the theoretical curve with a slope of 14.52 fluorescence units (slit $I, I \mathrm{X}$ ) based on the means of I I different experiments in which individual green hydra were measured $(n=87)$. Based on these experiments and data extrapolated from Fig. 2 we conclude that on the average approximately 100000 algae exist in each green hydra with a range of from 75000 to 250000 . This average is slightly reduced from estimates based on direct counts reported by Muscatine \& Pardy (1973). Line 


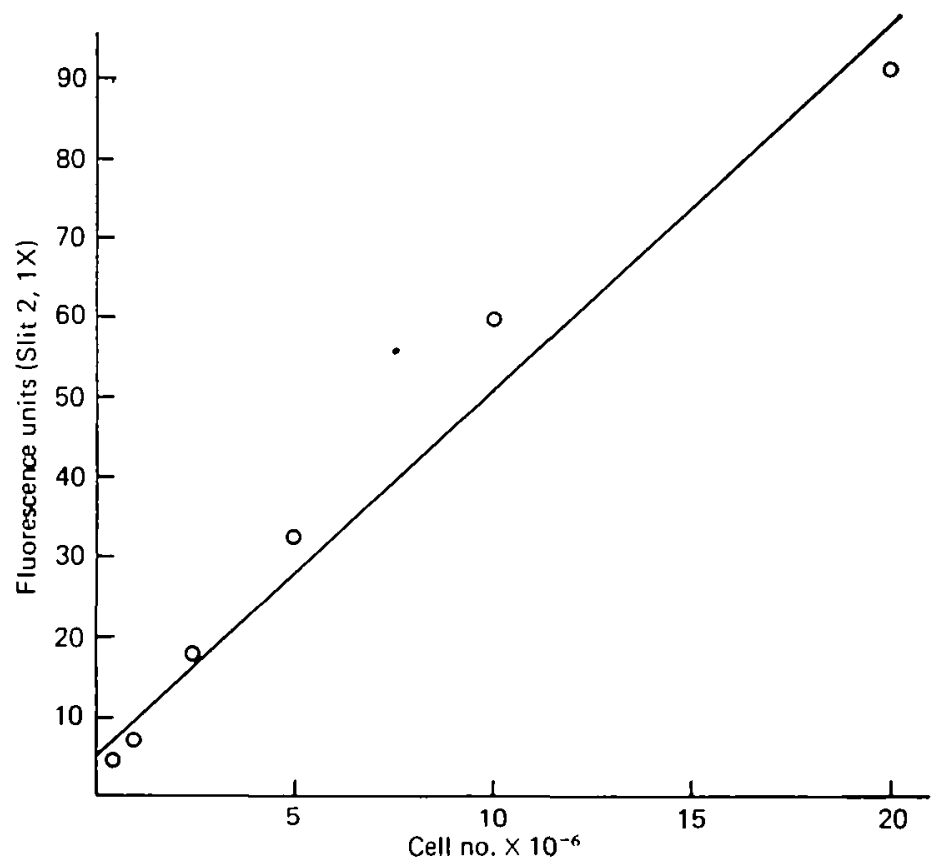

Fig. I. Chlorophyll content, as fluorescence units measured at low sensitivity, contained in algae symbiotically associated with $H y d r a$ viridis. The cells after preparation were extracted in $4 \mathrm{ml}$ methanol.

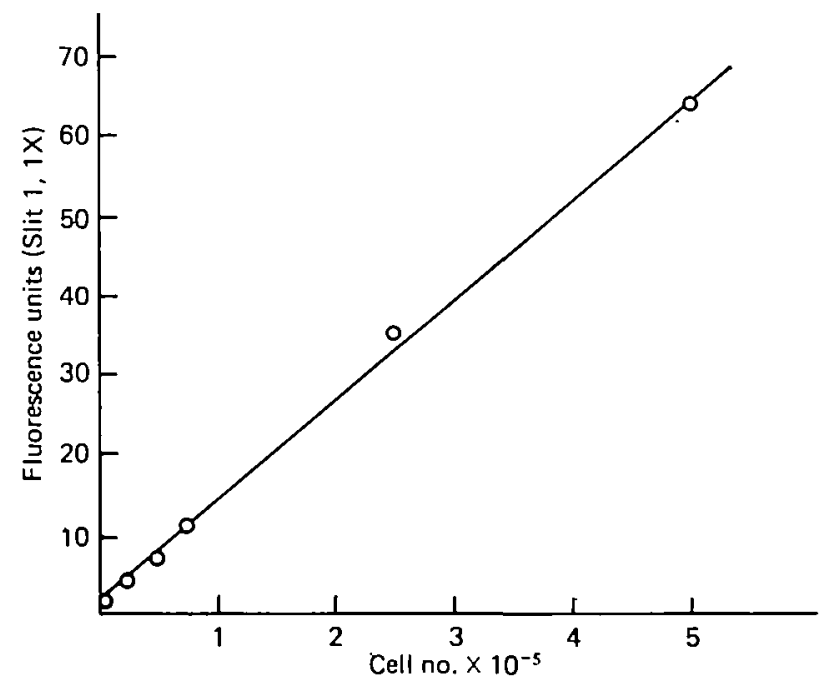

Fig. 2. Chlorophyll content, as fluorescence units measured at high sensitivity, contained in symbiotic algae. Extracts were performed in $4 \mathrm{ml}$ methanol. 


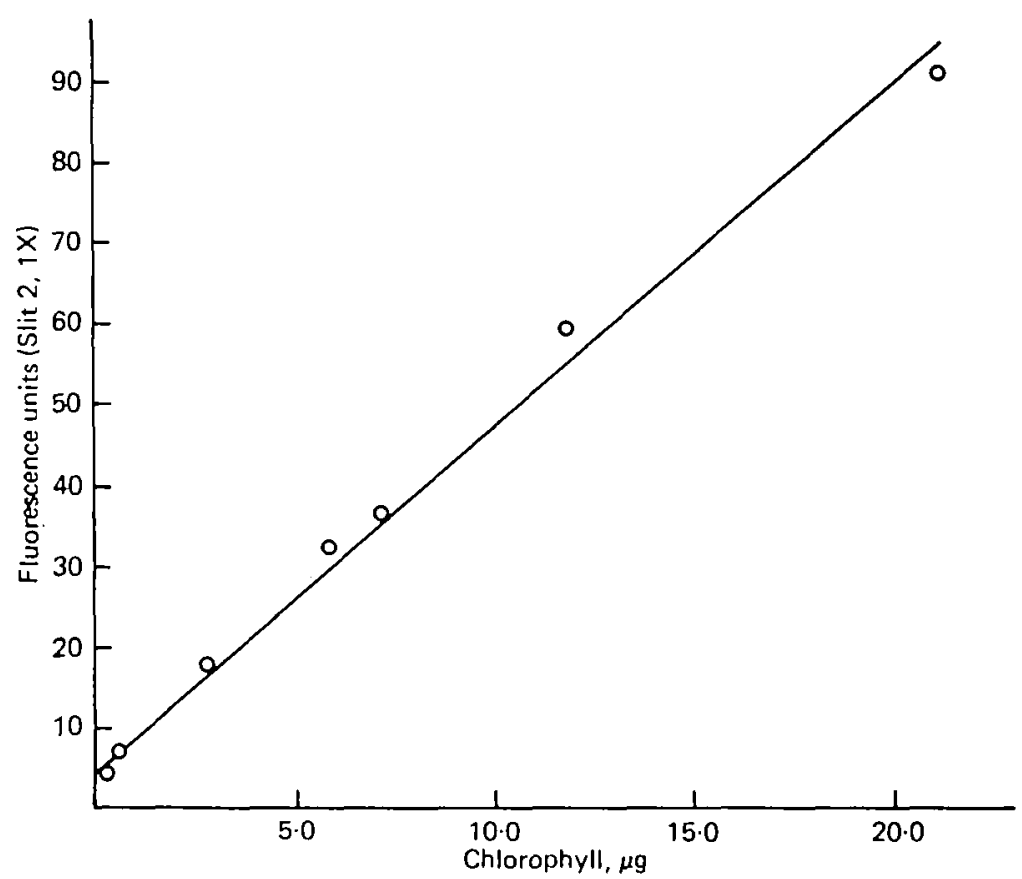

Fig. 3. Chlorophyll content, as fluorescence units, contrasted to spectrophotometric estimates from the same sample. All extracts of increasing cell numbers were extracted in $4-\mathrm{ml}$ volumes.

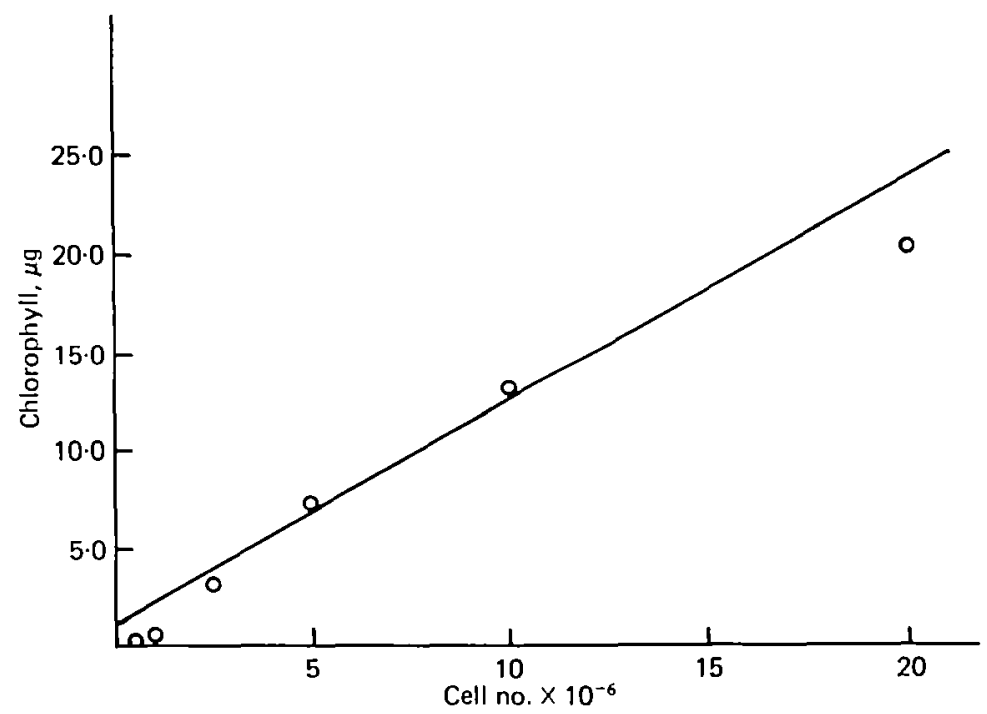

Fig. 4. Based on Figs. I and 3 the amount of chlorophyll compared to cell numbers may be extrapolated. 
$D$ of this curve shows that aposymbionts maintained in our culture system are algae free.

In order to establish the maximal level of algal uptake by aposymbionts, starved animals were used as recipients. In Fig. 6, it is demonstrated that a 48 -h starvation peried is optimal for maximal uptake of algae by injected aposymbionts. In all experiments reported in this study this starvation protocol was used. Since experimental treatment of algae requires varying amounts of time, the ability to maintain competent cells was determined for a 24 -h period. Clearly only minimal reduction in uptake of these cells when maintained in the dark in $\mathrm{M}$ solution at $4{ }^{\circ} \mathrm{C}$ was demonstrated (Fig. 7).

The results presented above demonstrate the utility of fluorimetric techniques in the analyses of host-symbiont reassociation experiments. Using these methods we investigated a range of factors suspected to be important in the biology of hydraalgae reassociation.

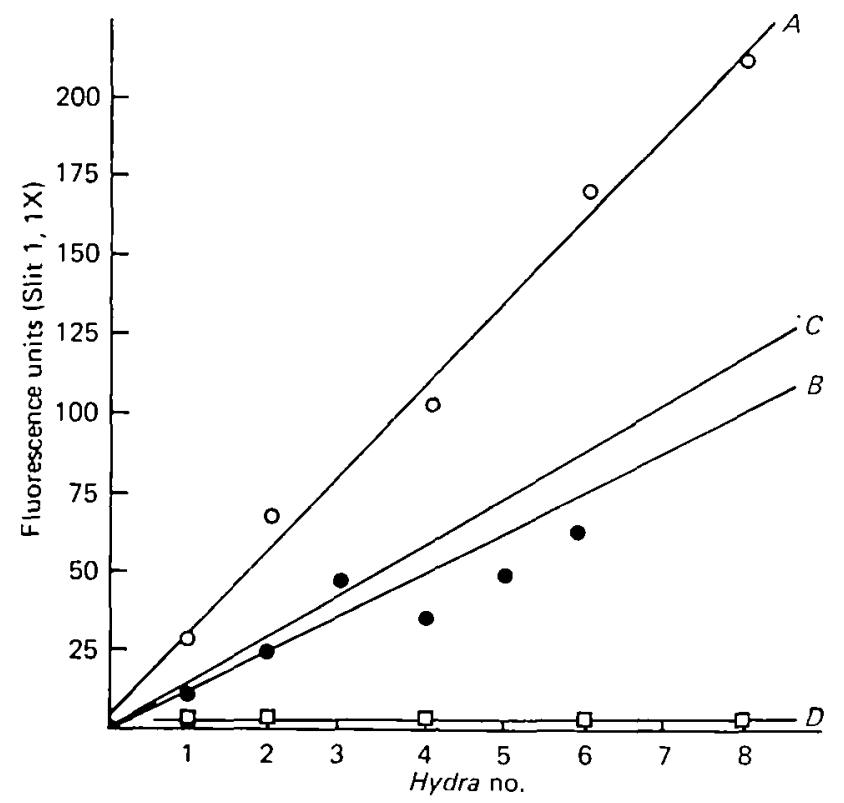

Fig. 5. Chlorophyll content, expressed as fluorescence units, for hydra ranging in number from $I$ to 8 animals. Lines $A$ and $B$, representing individual experiments, represent the range of 8 experiments $(n=87)$ of which $C$ is the regression line. Line $D$ indicates the algae-free hydra contain no chlorophyll.

In an initial set of experiments we analysed the uptake of symbionts originally isolated and cultured from Paramecium bursaria. These symbionts were cultured in either nutrient broth or on nutrient agar slants prior to injection of aposymbiotic hydra. Suspensions of cells from either broth or slants were injected into aposymbiotic recipients and the animals analysed $24 \mathrm{~h}$ post injection. Table I, Expt. I shows that the animals acquired the NC64A symbionts though the amounts of fluorescence were significantly $(P<0.01)$ less than in hydra injected with native symbionts. There was 
no significant difference $(P<0.0 \mathrm{I})$ between symbionts obtained from either broth or slant culture. Non-symbiotic Chlorella vulgaris was also injected; uptake of these algae was also minimal.

Preliminary observations had shown that algae harvested from whole animal homogenates contained particles of animal tissue and that this contamination, which

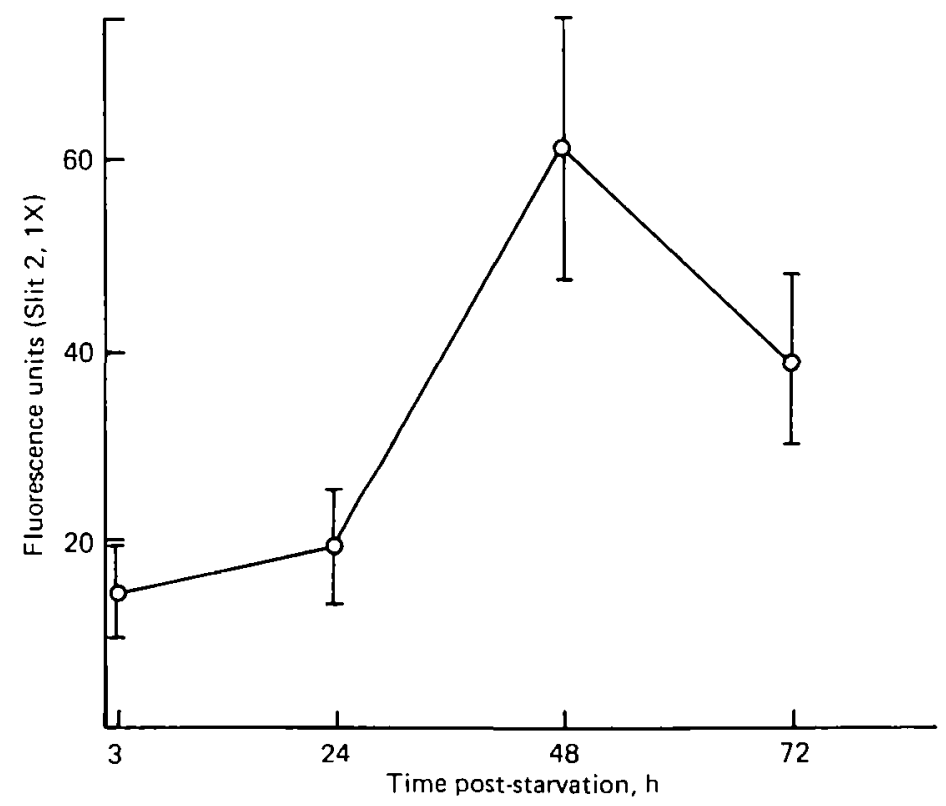

Fig. 6. Uptake of algae expressed as chlorophyll fluorescence, by hydra at various intervals after the last feeding on brine shrimp. Individual hydra with buds removed were extracted in $4 \mathrm{ml}$ methanol.

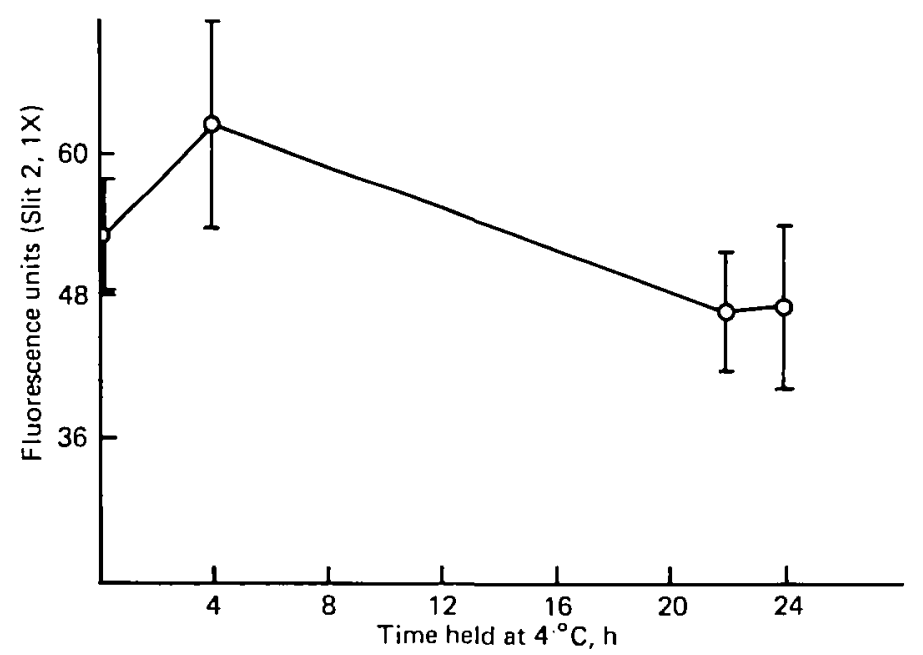

Fig. 7. Uptake of algae, expressed as chlorophyll fluorescence, by hydra after holding algal preparations at $4{ }^{\circ} \mathrm{C}$ for various periods. Hydra were extracted in $4 \mathrm{ml}$ methanol. No significant change from control is demonstrated $(P<0.01)$. 
was difficult to control, might affect the total number of algae taken up by an aposymbiont and/or the kinetics of reassociation. To solubilize and remove this debris, algae isolated from green hydra were washed with SDS (Materials and methods) prior to injecting aposymbionts. Twenty-four hours post injection the animals were analysed along with animals injected with unwashed algae. Table I, Expt. 2, shows the results of these experiments where it can be seen that the uptake of SDS-washed algae by aposymbionts was more than double that of the unwashed symbionts. Moreover, the

Table I. Effect of various algae types and treatments on reassociation with aposymbionts ( $n=8$ or more replicates)

\begin{tabular}{cllccc}
\hline & & & & $\begin{array}{c}\text { Fluorimetric } \\
\text { units, } \\
\text { Expt. }\end{array}$ & $\begin{array}{c}\text { Significance, } \\
P\end{array}$ \\
\hline \multirow{2}{*}{ I } & Algae source & Conditions & Wash & Slit 2(3X) & $\begin{array}{c}P \\
\end{array}$ \\
& GCen hydra & Standard culture & SDS & $30.84 \pm 20.65$ & \\
& NC64A & Agar slant & - & $1.13 \pm 0.23$ & $<0.001$ \\
& NC64A & Broth culture & - & $3.18 \pm 0.71$ & $<0.001$ \\
& NC64A & Agar slant & SDS & $3.56 \pm 3.23$ & $<0.001$ \\
& Chlorella vulgaris & Broth culture & SDS & $1.72 \pm 0.61$ & $<0.01$ \\
2 & Agar slant & SDS & $1.29 \pm 1.16$ & $<0.001$ \\
& Green hydra & Standard culture & - & $17.08 \pm 4.18$ & - \\
& Green hydra & Standard culture & SDS & $36.50 \pm 20.99$ & $<0.05$ \\
\hline
\end{tabular}

total number of algae acquired by aposymbionts after SDS washing approximated or exceeded the value observed in normal, standard green hydra. Furthermore, aposymbionts injected with SDS-treated algae remained fully populated for up to 28 days post injection. Pretreatment of Paramecium algae (NC64A) with SDS had no significant effect on their uptake by hydra aposymbionts (Table I, Expt. I).

The effect of symbiont uptake after pretreatment of algae or hydra with various plant lectins is shown in Table 2. Lectins were incubated with algae or injected into the enteron of the hydra, in the case of Con A (Expt. 4), for I h. The algae were washed 3 times before injection into hydra and the hydra enteron was cleared of Con A by injection of fresh M. All lectins surveyed depressed uptake below control (untreated) levels. Symbionts treated with Con A in particular showed a pronounced depression of uptake - almost zero (Expt. 5). Observed, but unanalysed variability, perhaps of a seasonal nature, was noted in the uptake of algae by control animals in some experiments. In order to determine whether cells were being taken up at all, in one experiment hydra were examined microscopically using established maceration techniques (David, I973). Table 3 shows that uptake per cell was indeed diminished severely and only $3 \mathrm{I} \%$ of cells screened had any algae at all.

To explore further the relationship between Con $A$ and the reduction of algal uptake by aposymbiotic hydra, a dose-response experiment was performed. SDSwashed algae were exposed to $100,500,1000$, and $2000 \mu \mathrm{g} / \mathrm{ml}$ Con A prior to injection into aposymbiotic hydra. Data from this experiment are presented in Fig. 8 and show that the degree of symbiont uptake decreases with increasing pre-injection concentrations of Con A. 
Table 2. Effect of lectins on uptake of algae when applied either to Algae or to Hydra ( $n=8$ or more replicates)

\begin{tabular}{|c|c|c|c|c|c|c|}
\hline Expt. & $\begin{array}{l}\text { Treated } \\
\text { subject }\end{array}$ & Treatment & $\begin{array}{c}\text { Concentrations, } \\
\mu \mathrm{g} / \mathrm{ml}\end{array}$ & $\begin{array}{c}\text { Fluorimetric } \\
\text { units } \\
\text { (Slit } 2,3 \mathrm{X} \text { ) }\end{array}$ & $P$ & $\begin{array}{l}\% \text { of } \\
\text { control }\end{array}$ \\
\hline I & $\begin{array}{l}\text { Algae } \\
\text { Algae }\end{array}$ & $\begin{array}{l}\text { Control } \\
\text { Lens culinaris lectin }\end{array}$ & $1000\left(\overline{1} 0^{8}\right.$ cells $)$ & $\begin{array}{l}42 \cdot 67 \pm 12 \cdot 40 \\
19 \cdot 00 \pm 12 \cdot 35\end{array}$ & $<0.01$ & $\begin{array}{l}100 \\
49^{\circ} I\end{array}$ \\
\hline 2 & $\begin{array}{l}\text { Algae } \\
\text { Algae }\end{array}$ & $\begin{array}{l}\text { Control } \\
\text { Ricin lectin }\end{array}$ & $\frac{-}{2500\left(10^{8} \text { cells }\right)}$ & $\begin{array}{l}82 \cdot 7 \pm 41 \cdot 36 \\
19 \cdot 7 \pm 9 \cdot 06\end{array}$ & $<\overline{0.01}$ & $\begin{array}{l}100 \\
23 \cdot 8\end{array}$ \\
\hline 3 & $\begin{array}{l}\text { Algae } \\
\text { Algae } \\
\text { Algae }\end{array}$ & $\begin{array}{l}\text { Control } \\
\text { WGA } \\
\text { WGA }\end{array}$ & $\begin{array}{c}-\overline{-} \\
2500\left(\mathrm{ro}^{8} \text { cells }\right) \\
5000\left(\mathrm{ro}^{8} \text { cells }\right)\end{array}$ & $\begin{array}{l}50 \cdot 75 \pm 20 \cdot 26 \\
28 \cdot 35 \pm 18 \cdot 64 \\
24 \cdot 39 \pm 16 \cdot 94\end{array}$ & $\begin{array}{l}<0.02 \\
<0.01\end{array}$ & $\begin{array}{l}100 \\
55 \cdot 9 \\
48 \cdot 1\end{array}$ \\
\hline 4 & $\begin{array}{l}\text { Hydra } \\
\text { Hydra }\end{array}$ & $\begin{array}{l}\text { Control } \\
\text { Con A }\end{array}$ & $10^{-}$ & $\begin{array}{l}72 \cdot 91 \pm 38 \cdot 14 \\
33 \cdot 58 \pm 20 \cdot 26\end{array}$ & - & $\begin{array}{l}\text { 100 } \\
57 \cdot 3\end{array}$ \\
\hline 5 & $\begin{array}{l}\text { Algae } \\
\text { Algae } \\
\text { Algae }\end{array}$ & $\begin{array}{l}\text { Control } \\
\text { Con A } \\
\text { Con A }\end{array}$ & 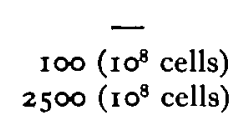 & $\begin{array}{r}26 \cdot 68 \pm 7 \cdot 57 \\
18 \cdot 50 \pm 5 \cdot 44 \\
1 \cdot 75 \pm I \cdot 28\end{array}$ & $\begin{array}{l}<0.02 \\
<0.001\end{array}$ & $\begin{array}{r}100 \\
69 \cdot 3 \\
6 \cdot 4\end{array}$ \\
\hline
\end{tabular}

Table 3. Effect of Concanavalin $A$ on algal uptake as measured by microscopical analysis

\begin{tabular}{ccccc}
\hline$n$ & Treatment & $\begin{array}{c}\text { Concentration, } \\
\mu \mathrm{g} / \mathrm{ml}\end{array}$ & $\begin{array}{c}\% \text { digestive } \\
\text { cells with } \\
\text { algae }\end{array}$ & $\begin{array}{c}\text { Algae/digestive } \\
\text { cell }\end{array}$ \\
\hline 50 & Control & - & 100 & $10 \cdot 92 \pm 3.48$ \\
54 & Con A & $2500\left(10^{8}\right.$ cells $)$ & $3 \mathrm{I}$ & $\mathrm{I} \cdot 00 \pm \mathrm{I} \cdot 90$ \\
\hline
\end{tabular}

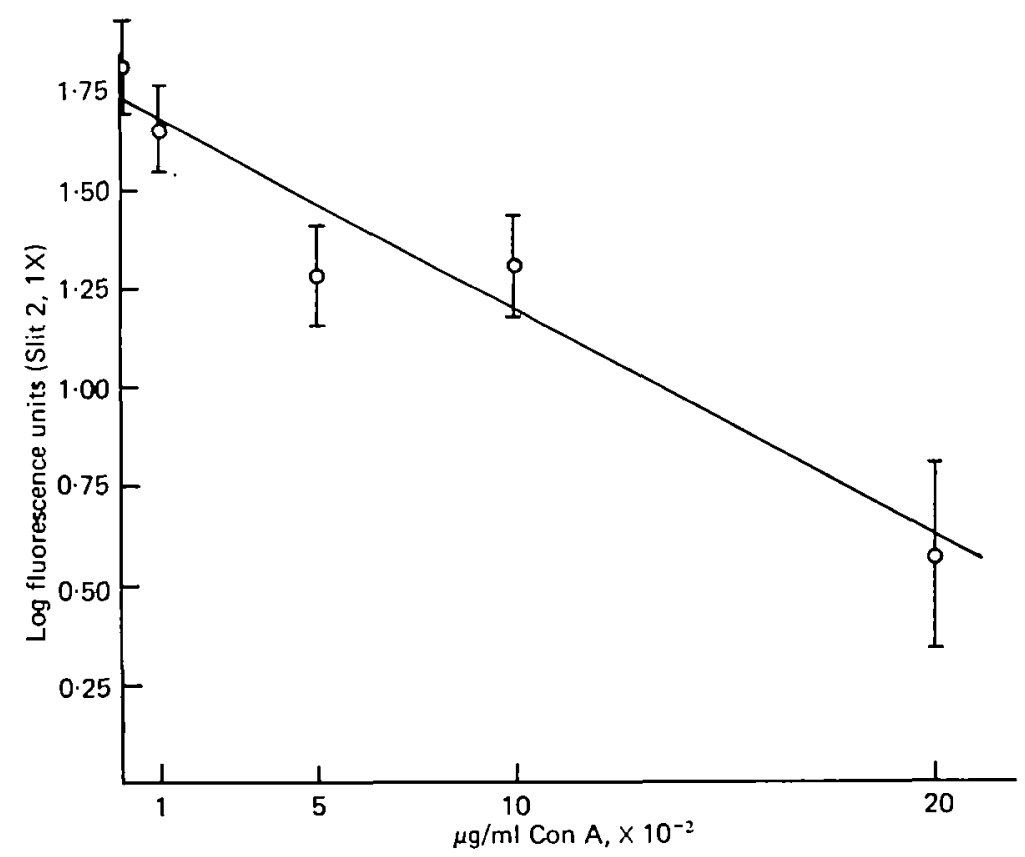

Fig. 8. Uptake of algae, expressed as log fluorescent units, after treatment with increasing doses of Con A. Hydra were individually extracted in $4 \mathrm{ml}$ methanol. Each point represents 8 replicate measurements. 


\section{DISCUSSION}

The underlying significance of the past studies of the effect of symbiotic algae on the growth and development of their invertebrate hosts has been guided by 2 objectives: (I) to establish a nutritional relationship between partners; and (2) to characterize the chemical basis of this relationship (Muscatine, r96r).

The observation that symbiont partner surfaces play an important role in initiating experimental reassociation confirmed by this study extends those objectives. Reported inhibition of these complex uptake events by specific antibody (Pool, 1978) or studies of uptake specificity (Pardy \& Muscatine, I973) can now be explained on the basis of specific interaction of plant cell wall with hydra digestive membranes.

With the present study we have begun to elaborate on the initial events of reassociation. New methods are described in this study for quantitative demonstration of recognition events. Based on chlorophyll's fluorescent emissions after proper excitation, this analysis is rapid, precise and reproducible. Furthermore, samples are stable and analyses can be carried out after sampling for intervals of up to at least $96 \mathrm{~h}$.

Results reported here demonstrate that the amount of emission measured from algal samples with increasing cell numbers is linear in response and directly proportional to cell numbers. These studies using large samples of algae taken from standard normal green animals assume a standard random amount of chlorophyll per each cell. They do not recognize various possibilities of different developmental or metabolic states for each alga nor any type of population dynamics. These would have to be controlled in individual subsequent experiments.

The samples measured fluorimetrically can also be measured spectrophotometrically permitting a direct calibration of fluorimetric emission to total amounts of chlorophyll. Thus the numbers of algae and amount of chlorophyll in green hydra may be estimated. These studies show that a sample as small as a single green hydra can be measured and that fluorimetric emission shows a linear response with increasing numbers of these hydra per sample.

The demonstration that algal cell surfaces and hydra digestive cell membranes play an active role in initial recognition has been hypothesized for some time. This general conception of active recognition versus random association followed by phagocytosis is predicated upon early observations that not all algae were equally competent in symbiotic reassociations. Karakashian (1975) has extensively surveyed reassociation in the algal-paramecium system. Clearly different strains and variously treated native symbionts are different in their ability to form long-term maintenance of the partnership. The success ranges from complete and persistent reassociation with native algae to much reduced or no reassociation with wild type chlorella or heat-treated native forms. The major question left unanswered by their studies is whether the 'success' or lack thereof is a property of the cell surface in terms of recognition or whether this phenomenon occurred internally as the result of other 'decision making' processes after random (= uncontrolled) phagocytosis. The later hypothesis includes the requirement of the algae to synthesize or transport small molecules such as maltose for long-term maintenance. 
Recently Pool (1979) has provided critical evidence that uptake of symbionts by the digestive cells can be inhibited by pretreatment of native symbionts with antibody specifically elicited to living algal symbionts. Cross-reacting antigenic determinants are not shared by in vitro cultured algae of strains ( $\mathrm{NC}_{4} \mathrm{~A}$ ) originally derived from Paramecium but which have some reduced capability of uptake by hydra. On the other hand once the reduced uptake results in successful reassociation antigenic sites are induced on NC64A algae during residence in the hydra digestive cells.

The present study provides evidence for successful symbiont reassociation using yet another probe for cell surface function. Lectins specific for a variety of cell surface sites have been widely used for demonstration of surface activity. One such lectin, Con A characteristically binds several sugar moieties common to a variety of cell surface glycoproteins. We have found that Con A, as well as WGA, Lens culinaris lectin, or ricin, is successful in blocking symbiont uptake. Several algal cell wall surface carbohydrates along with arabinosides of cell wall glycoprotein are putative candidates for successful binding of lectins to the symbiont. Using radiolabelled Con A (unpublished results) we have shown strong binding of lectin to these cells.

The data of our study show that with increasing concentrations, Con A progressively inhibits the uptake of algae by hydra to minimal levels at high concentrations. These concentrations are considerably higher than those typically studied on animal cells suggesting that many more binding sites may be present. Even though we suppose that the lectin is binding to specific sites on the algae, we cannot deny potential adsorption of the molecules to the algae and the actual subsequent action of lectin on the digestive cell of the hydra. As is conspicuously the case, much lower concentrations of Con A (in the range of $100 \mu \mathrm{g} / \mathrm{ml}$ ) typically inhibit animal cell membrane activities. In preliminary studies we are able to inhibit uptake by concentrations one-tenth this level by application of Con A through injection, to the digestive cell membrane and before injection of the algae into the hydra enteron. Thus we must conclude that sites on both algae and host digestive cells are inhibitable by Con A.

The actual mechanism for inhibition is not fully elucidated by this study. While we would like to believe that Con A binds directly to a specific site located on competent native algae, neither these results nor we believe those of Pool (1979) can be unequivocally interpreted in this way. We recognize that both lectins and antibodies could act by masking the recognition sites. As the result of extensive molecular binding, recognition sites cryptic on either algae or digestive cell would be sterically out of reach of the reaction sites of the other partner. On the other hand, it can be argued that even if surface binders act by a masking effect, one may infer surface recognition sites, capable of being masked. While we cannot definitely argue that glycans or glycoproteins from the surface are specific for recognition, our data are compatible with this hypothesis. Studies are presently underway which will further examine specific recognition mechanisms and determine whether specific molecular structures are involved in the process. 


\section{REFERENCES}

Burger, M. M. (1969). A difference in the architecture of surface membrane of normal and virally transformed cells. Proc, natn. Acad. Sci. U.S.A. 62, 994-1001.

Cuatrecasas, P. (i 973). Insulin receptor of liver and fat cell membranes. Fedn Proc, Fedn Am. Socs exp. Biol. 32, $1838-1846$.

Cuatrecasas, P. (1974). Membrane receptors. A. Rev. Biochem. 43, I69-2 I 4.

David, C. N. (I973). A quantitative method for maceration of hydra tissue. Wilhelm Rotux Arch. EntwoMech. Org. I7I, 268-295.

Edidin, M. (1976). Cell surface antigens in mammalian development In Cell Surface Reviezs (ed. G. Poste \& G. L. Nicolson), pp. 127-r 43. Amsterdam: North-Holland.

EDIdin, M. \& Weiss, A. (I 972). Antigen cap formation in cultured fibroblasts: a reflection of membrane fluidity and cell motility. Proc. natn. Acad. Sci. U.S.A. 69, 2456-2459.

Goldstein, I. J. \& So, L. L. (1965). Protein-carbohydrate interaction. III. Agar gel-diffusion studies on the interaction of Concanavalin A, a lectin isolated from jack bean with polysaccharides. Archs Biochem. Biophys. II I, 407-4I4.

Inbar, M., Ben-Bassat, H. \& SaChs, L. (I971). Location of amino acid and carbohydrate transport sites in the surface membrane of normal and transformed mammalian cells. F. Membrane Biol. 6, I95-209.

Karakashian, M. W. (1975). Symbiosis in Paramecium bursaria. In Symbiosis (ed. D. H. Jennings \& D. L. Lee), pp. I 45-I 74. Cambridge, U.K. : Cambridge University Press.

LeNHoff, M. H. \& Brown, R. D. (1970). Mass culture of hydra: an improved method and its application to other aquatic invertebrates. Lab. Animals 4, r 39-1 54.

Loor, F., Formi, F. \& Pernis, B. (1972). The dynamic state of the lymphocyte membrane. Factors affecting distribution and turnover of surface immunoglobulins. Eur. F. Immun. 2, 203-2I 2.

Mackinney, G. (I94I). Absorption of light by chlorophyll solutions. F. biol. Chem. 140, 3I 5-322.

Moscona, A. A. (1974). Surface specifications of embryonic cells: Lectin receptors, cell recognition, and specific cell ligands. The Cell Surface in Development (ed. A. A. Moscona), pp. 67-99. New York: Wiley.

Muscatine, L., Cook, C. B., Pardy, R. L. \& Pool, R. R. (1975). Uptake, recognition and maintenance of symbiotic Chlorella by Hydra viridis. Symp. Soc. exp. Biol. 29, 175-203.

Oseroff, A. R., Robins, P. W. \& BUrger, M. M. (1973). The cell surface membrane: biochemical aspects and biophysical probes. A. Rev. Biochem. 42, 647-682.

Pardy, R. L. (1976). The production of aposymbiotic green hydra by the photodestruction of their symbiotic algae. Biol. Bull. mar. biol. Lab., Woods Hole. I51, 225-235.

Pardy, R. L. \& Muscatine, L. (I973). Recognition of symbiotic algae by Hydra viridis. A quantitative study of the uptake of living algae by aposymbiotic $H$. viridis. Biol. Bull. mar. biol. Lab., Woods Hole 145, 565-579.

Pool, R. R. (1979). The role of algal antigenic determinants in the recognition of potential algal symbionts by cells of Chlorohydra. F. Cell Sci. 35, 367-379.

Rosen, S. D., Kafka, J. A., Simpson, D. L. \& Barondes, S. H. (i973). Developmentallyregulated carbohydrate-binding protein in Dictyostelium discoideum. Proc. natn. Acad. Sci. U.S.A. 70, $2554^{-2557 .}$

Sharon, N. \& Lis, H. (г972). Lectins: Cell-agglutinating and sugar-specific proteins. Science, N.Y. 177, 949-959.

So, L. L. \& Goldstein, I. J. (I967). Protein-carbohydrate interaction. IV. Application of the quantitative precipitin method to polysaccharide-Concanavalin A interaction. $\mathcal{F}$. biol. Chem. 242, 16 I 7-1622.

Yahara, J. \& Edelman, G. M. (i 972). Restriction of the motility of lymphocyte immunoglobulin receptors by Concanavalin A. Proc. natn. Acad. Sci. U.S.A. 69, 608-6r2.

(Received 2 fuly 1979 - Revised 7 November 1979) 